\title{
Policy and Global Affairs
}

Quick Links

ACTIVITIES AND REPORTS

U.S. NATIONAL COMMITTEES BISO MEMBERSHIP AND STAFF

\section{OPPORTUNITIES}

APA-USNC/IUPsyS Trave

Fellowship to ICP 2012

Deadline: December 31, 2011

More information.

IDA STPI Baccalaureate

Fellows Program

Deadline: January 13, 2012

More information..

The Jefferson Science

Fellowship

Deadline: January 13,2012

More information..

AIP Congressional Science

Fellowship Program

Deadline: January 15, 2012

More information.
BISO Home $>$ USNCFUBS $>$ Biological Sciences for the 21st Century

Biological Sciences for the 21st Century: Meeting the Challenges of Sustainable Development in an Era of Global Change

A symposium exploring exciting developments in biological sciences research and how these developments could be harnessed to address world-wide challenges of promoting sustainable development in an era of global change

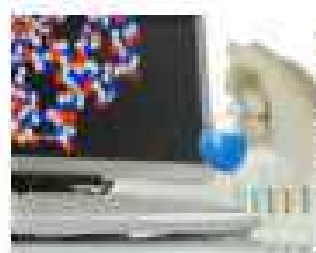

Session 1: Overvlews of Key Developments in the Biological Sciences

The Biological Sciences and the Challenge of Sustainability

William Clark. Harvard University, USA

Biocomplexity Applications in Addressing Global Issues

Rita Colwell, University of Maryland, USA

Advances and Challenges in Computational Biology

Stephen Emmott, Microsoft Research Cambridge, UK

Request a Sympostum CD

Request a CD containing speaker presentations and audio/video tracks.

CDs of the materials from the "Biological Sciences for the 21st

Century" symposium are being

produced. If you would like to

request one, kindly send your

name, mailing address, and

contact information to

3isolonas edu. Please include

the heading "May 2007 IUBS CD

Request" in the subject line of your

message.

Advances in Molecular Techniques

Claire Fraser-Liggett, University of Maryland School of Medicine, USA

Advances in Integrating Knowiedges

Jan Salick, Missouri Botanical Garden, USA

Advances in Capacity Building

Ismail Serageldin, The Library of Alexandria, Egypt

Session 2: The Challenge of Ecosystem Services 
Quick Links

ACTIVITIES AND REPORTS

U.S. NATIONAL COMMITTEES BISO MEMBERSHIP AND STAFF

\section{OPPORTUNITIES}

APA-USNCIUPsyS Trave

Fellowship to ICP 2012

Deadline: December 31, 2011

More information...

IDA STPI Baccalaureate

Fellows Program

Deadline: January 13,2012

More information.

The Jefferson Science

Fellowship

Deadline: January 13, 2012

More information.

AlP Congressional Science

Fellowship Program

Deadline: January 15, 2012

More information...
BISO Home $>$ USACYIUES $>$ Biological Sciences for the 21st Century

Biological Sciences for the 21st Century: Meeting the Challenges of Sustainable Development in an Era of Global Change

A symposium exploring exciting developments in biological sciences research and how these developments could be harnessed to address world-wide challenges of promoting sustainable development in an era of global change

\section{Wexp Session 1: Overviews of Key Developments in the Biological Sclences

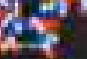 \\ The Biological Sciences and the Challenge of Sustainability \\ William Clark, Harvard University, USA \\ Biocomplexity Applications in Addressing Global Issues}

Rita Colwell, University of Maryland, USA

Advances and Challenges in Computational Biology

Stephen Emmott, Microsoft Research Cambridge, UK

Request a Sympositum CD

\section{Request a CD containing}

speaker presentations and audio/video tracks.

CDs of the materials from the "Blological Sciences for the 21st

Century" symposium are being

produced. If you would like to

request one, kindly send your

name, mailing address, and

contact information to

BISORanas edu. Please include

the heading "May 2007 IUBS CD

Request" in the subject line of your

message.

Advances in Molecular Techniques

Claire Fraser-Liggett, University of Maryland School of Medicine, USA

Advances in Integrating Knowiedges

Jan Salick, Missouri Botanical Garden, USA

Advances in Capacity Building

Ismail Serageldin, The Library of Alexandria, Egypt

Session 2: The Challenge of Ecosystem Services 
IIASA 2012 Young Scientists Summer Program

Deadline: January 16,2012

More information

Travel Fellowships to ICTAM

Deadline: January 31,2012

More information...

34th International Geologica

Congress Travel Grant and

Mentoring Program

Deadline: February 17, 2012

More information...

IIASA Postdoctoral Program Deadline: February 29, 2012 More information...

\section{DID YOU KNOW?}

All PDF versions of reports published by the National Academies Press are now downloagdabie ta readers worldwide froe of change.

The international Visitors Office is a good resource for visa-related issues.

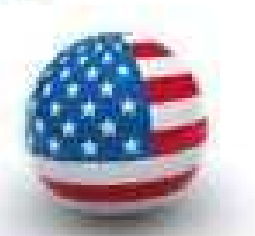

Contact BISO

Board on International

Scientific Organizations

Poicy and Global Affairs
Natural Security: Ecosystems and Human Well-Being

Jane Lubchenco, Oregon State University, USA

Complex Systems and the Challenge of Ecosystem Services

Simon Levin, Princeton University, USA

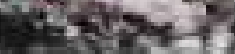

A Bountiful Harvest: Using What We Already Know and Will Know James Reichman, University of California - Santa Barbara, USA

The Development of a Predictive Model for the Control of the Desert Locust

Onesmo ole-Moîoi, International Center of Insect Physiology \& Ecology (ICIPE), Kenya

Integrating Local and Scientific Knowiedge Surrounding Tropical Ecosystem Goods \& Services: Avallability, Use and Policies Lisa Curran, Yale School of Forestry \& Environmental Studies, USA

Discussion on Capacity Bullding

Kamal Bawa, University of Massachusetts- Boston, USA

Onesmo ole-MoiYoi, International Center of Insect Physiology \& Ecology (ICIPE), Kenya

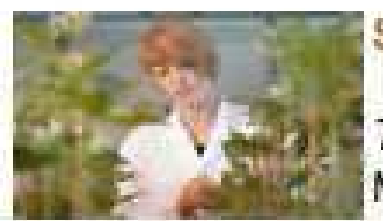

Session 3: The Challenge of Food Security

Threats to an Evergreen Revolution in Agriculture

M.S. Swaminathan, M.S. Swaminathan Research Foundation, India

Putting it all Together at the Grass Roots in African Green Revolution

Pedro Sanchez, The Earth Institute at Columbia University. USA

Maize Genome Assembly, Mapping and Biofuels

Patrick Schnable, lowa State University, USA

Using Livestock Diversity to Understand Genome Biology

Stephen Kemp, International Livestock Research Institute (ILRI), Kenya and University of Liverpool, UK

Knowledge Integration and Problem-solving for Sustainable Agriculture

Calestous Juma, Harvard University, USA

Capacity Building in the Blological Sciences for Food Security

Meryl Williams, Australian Centre for International Agricultural Research, Australia

Session 4: The Challenge of Population Health 
Large-scale Genome Sequencing and Analysis of the Influenza Virus

Steven Salzberg, University of Maryland, USA

Can Microbial Genomics and Proteomics Contribute to Improve Human Health in the 21st Century? Yu-Mei Wen, Fudan University, P.R. China

The Promise of an Integrative Approach, Combining Ayurvedic Knowledge with Westem Bio-medical Sciences Darshan Shankar, Foundation for Revitalisation of Local Health Traditions, India

Capacity Bullding in Biology and Public Health in the 21st Century

Ulisses Confalonieri, National School of Public Health, Brazil

\section{Session 5: The Energy Challenge}

Genomics: Key for Ecological Studies, Renewable Fuel Production, and the Stabilization of Atmospheric Carbon J. Craig Venter, J. Craig Venter Institute, USA

\section{Commentary}

Corrado Clini, Ministry for Environment, Land and Sea, Italy

Anna Palmisano, United States Department of Agriculture

Session 6: Transforming Research Into Solutions

Discussion by world leaders in science policy, reflecting the content of the symposium and looking to the future

\section{Education for Sustainability}

A half-day symposlum featuring strategles for the effective teaching of sustainablity sclence

Introduction by the Symposium Organizer

John R. Jungck, Beloit College, Chairperson, U. S. National Committee to IUBS and Vice President, IUBS Commission on Biology Education 


\section{Education for Sustainability}

A half-day symposium featuring strategles for the effective teaching of sustainability science

Introduction by the Symposium Organizer

John R. Jungck, Beloit College, Chairperson, U. S. Nationai Committee to IUBS and Vice President, IUBS Commission on Biology Education

History of the IUBS Commission on Biology Education

Talal Younes, Executive Director of IUBS, France

Maori and Westem World Views Shape a Strong Environmental Ethic in Aotearoa/New Zealand

Charles H. Daugherty, Assistant Vice-Chancellor (Research); Professor of Ecology, Victoria University of Wellington, New Zealand

Co-author: Kristina Ramstad

Data Enriched Sustainability in a Megabiodiverse World - Challenges and Potentials

Vishwas Chavan, Scientist, Information Division, National Chemical Laboratory, Pune, India

Engaging Students in Sustainability Issues: Investigative Cases, Tools and Data

Margaret Waterman, Professor of Biology \& Director, Center for Teaching and Learning, Southeast Missouri State University and Associate Director, BioQUEST Curriculum Consortium

Towards a New Generation of Naturalist Citizens: INBio's Bioliteracy Program

Natalia Zamora, Director, National Biodiversity Institute (INBioParque), Costa Rica

Practicing Education for Sustainable Development through Environmental Action Learning: A Case of Eco-schools in Kenya

Dorcas Otieno, Director Kenya Organization for Environmental Education

Teaching and Mediating Sustainability Science

Andre Giordan, President, IUBS Commission on Biology Education and Founder and Professor, the Laboratoire de Didactique et Epistemologie des Sciences (LDES), University of Geneva, Switzerland

Steering Committee for Biological Sciences for the 21st Century:

Meeting the Challenges of Sustainable Development in an Era of Glocal Change

William Clark (Chair)

Harvard University

Bruce Alberts

University of California, San Francisco

Rita Colwell

University of Maryland
Tony McMichael

The Australian National University

M.S. Swaminathan

Pugwash Conferences on Science and World Affairs

John C. Wooley

University of California, San Diego 
Steering Committee for Biological Sciences for the 21st Century:

\section{Meeting the Challenges of Sustainable Development in an Era of Glocal Change}

William Clark (Chair)

Harvard University

Bruce Alberts

University of California, San Francisco

Rita Colwell

University of Maryland

Claire Fraser-Liggett

University of Maryland School of Medicine

\section{Mohamed Hassan}

Academy of Science for the Developing World (TWAS)

Jane Lubchenco

Oregon State University

Julia Marton-Lefèvre

World Conservation Union

Support for This Meeting Was Generously Provided By:

- The Alfred P. Sioan Foundation

- American Institute of Biological Sciences

- Association of College and University Biology Educators

- BIOQUEST Curriculum Consortium

- The David and Lucle Packard Foundation

- Ford Foundation (New Delhi)

- International Union of Biological Sciences

- The John D. and Catherine T. MacArthur Foundation

- Monsanto Company
Tony McMichael

The Australian National University

M.S. Swaminathan

Pugwash Conferences on Science and Worid Affairs

John C. Wooley

University of California, San Diego

Ex Officio

Kamal Bawa

University of Massachusetts, Boston

Joel Cracraft

American Museum of Natural History

Marvalee Wake

University of California, Berkeley

\footnotetext{
- Museum of Comparative Zoology, Harvard University

- National Academy of Sciences

- National Association of Biology Teachers

- National Sclence Foundation

- The Society for Integrative and Comparative Biology

- The Society for Mathematical Biology

- United States Department of Energy

- United States Geological Survey
} 